\title{
PENINGKATAN AKTIVITAS DAN HASIL BELAJAR IPS MELALUI IMPLEMENTASI STRATEGI PETA KONSEP DI SMP MUHAMMADIYAH 3 DEPOK
}

\author{
Wiwik Hendriani, Aman \\ SMP N 12 Solok Selatan, FIS Universitas Negeri Yogyakarta \\ wiwikhendriani@ymail.com, aman@uny.ac.id
}

\begin{abstract}
Abstrak
Tujuan penelitian ini adalah untuk 1) mendiskripsikan implementasi strategi peta konsep untuk meningkatkan aktivitas dan hasil belajar IPS peserta didik, 2) meningkatkan aktivitas dan hasil belajar IPS peserta didik melalui implementasi strategi peta konsep, dan 3) mengetahui kendala-kendala dan cara mengatasi kendala yang dihadapi dalam meningkatkan aktivitas dan hasil belajar peserta didik dalam pembelajaran IPS . Penelitian tindakan kelas ini diimplementasikan pada peserta didik kelas VIII D SMP Muhammadiyah 3 Depok Sleman karena terindikasi bahwa aktivitas dan hasil belajar peserta didik pada pembelajaran IPS masih rendah. Teknik pengumpulan data yang digunakan berupa observasi, wawancara, tes dan dokumentasi. Aktivitas peserta didik mengalami peningkatan yaitu dari rerata keseluruhan 3,39 atau senilai 67,8 pada siklus I menjadi 3,48 yaitu senilai 70 pada siklus II yaitu klasifikasi cukup menjadi baik. Hasil belajar peserta didik yang mencapai nilai KKM pada siklus I sebanyak 14 orang yaitu sekitar $43,75 \%$ dan meningkat pada siklus II menjadi 28 orang dengan persentase $85 \%$. Kendala-kendala yang dihadapi ini adalah masih lemahnya manajemen waktu dari peneliti dalam proses pembelajaran serta penilaian terhadap aktivitas peserta didik karena terbatasnya pengamatan terhadap mereka dan kadang bersifat subjekif. Upaya mengatasi kendala yang dihadapi dengan pengalokasian waktu yang ketat dalam proses pembelajaran dan penilaian aktivitas peserta didik dapat dilakukan dengan penilaian antar mereka.
\end{abstract}

Kata kunci: aktivitas, hasil belajar, strategi peta konsep

\section{IMPROVING STUDENTS' ACTIVITIES AND LEARNING OUTCOMES IN SOCIAL STUDIES THROUGH THE IMPLEMENTATION OF CONCEPT MAPPING STRATEGY AT SMP MUHAMMADIYAH 3 DEPOK}

\author{
Wiwik Hendriani, Aman \\ SMP N 12 Solok Selatan, FIS Universitas Negeri Yogyakarta \\ wiwikhendriani@ymail.com, aman@uny.ac.id
}

\begin{abstract}
This study aims: 1) describe the implementation of the concept mapping strategy to improve the students' activity and the learning outcomes in social studies, 2) increase the students'activity and learning outcomes in social studies through the implementation of the concept mapping strategy 3) determine the obstacles and how to over come them in order to increase the students' activity and learning outcomes through the implementation of the concept mapping strategy. This research was implemented to the students in class VIII D SMP Muhammadiyah 3 Depok, Sleman since it was indicated that the activity and the learning outcomes of the students in learning social studies is was still low. The data collection techniques used were observation, interview, test and documentation. The students' activities have improved from the overall mean 3.39 or 67,8 in the first cycle to 3.48 or 70 in the second cycle that is from enough into good. The result of the postest of the students who achieved the KKM in the first cycle was 14 students or $43.75 \%$ and has increased in the second cycle to 28 students or $85 \%$ from all students. The constraints faced are still weak time management of researchers in the learning process as well as an assessment of the activity of learners because of the limited observations of them and sometimes are subjekif. Efforts to overcome the obstacles faced with tight time allocation in the process of learning and assessment activities students can do with their inter-assessment.
\end{abstract}

Keywords: activities, learning outcomes, concept mapping strategy 


\section{Pendahuluan}

Ilmu Pengetahuan Sosial merupakan mata pelajaran yang penting di sekolah atau masyarakat sekalipun, karena di dalamnya tergabung empat macam bidang ilmu yang memiliki kebermaknaan. Mempelajari Ilmu Pengetahuan Sosial dapat membantu manusia atau peserta didik untuk bersosialisasi dan beradaptasi di lingkungannya. Keberhasilan peserta didik bersosialisasi di lingkungannya menunjukan keberhasilan dalam pembelajaran. Berbagai masalah pembelajaran juga muncul karena begitu luasnya cakupan materi yang harus di kuasai oleh peserta didik. Untuk itu guru harus mampu menanamkan konsep materi pelajaran agar lebih mudah di pahami oleh peserta didik, sehingga keterpaduan dalam pembelajaran IPS dapat terlaksana dengan baik, sehingga peserta didik mampu beradaptasi dengan baik di lingkungannya.

Tujuan utama IPS ialah membina anak didik menjadi warga negara yang baik, yang memiliki pengetahuan, keterampilan, dan kepedulian sosial yang berguna bagi diri sendiri serta masyarakat dan negara (Nursid Sumaatmadja (2006, p.1.10). Mencapai itu semua keberadaan guru sangat penting dalam mempersiapkan segala sesuatu yang dibutuhkan peserta didik dalam proses pembelajaran. Guru harus menguasai banyak pengetahuan dalam bidangnya dan memiliki keterampilan menerapkan strategi pembelajaran yang sesuai dengan karakteristik materi pelajaran, yang berbeda antar satu dengan yang lainnya.

Berdasarkan observasi awal di SMP Muhammadyah 3 Depok Sleman Yogyakarta pada 31 Juli 2013 sampai dengan 10 September 2013 dapat diketahui bahwa aktivitas dan hasil belajar pembelajaran IPS masih rendah. Masih terdapat peserta didik yang belum mencapai nilai KKM (75) yang telah ditetapkan oleh guru. Aktivitas peserta didik dalam pembelajaran IPS masih rendah dan pembelajaran guru hampir tidak pernah menggunakan media pembelajaran.

Hasil ulangan harian pertama pada standar kompetensi satu yang diperoleh peserta didik semester satu (I) kelas VIIID SMP Muhammdiyah 3 Depok Sleman Daerah Istimewa Yogyakarta menunjukkan rerata kelas yaitu 70, 12. Ada 26 orang peserta didik yang belum mencapai nilai KKM 75. Nilai ini menunjukkan bahwa belum tercapainya nilai KKM klasikal 85\%.
Permasalahan dalam penelitian ini adalah aktivitas dan hasil belajar peserta didik dalam pembelajaran ilmu pengetahuan sosial yang masih rendah. Penggunaan media bantu oleh guru dalam pembelajaran masih sangat minim. Dengan menganalisis permasalahan di atas maka implementasi strategi peta konsep dalam proses pembelajaran IPS dapat meningkatkan aktivitas dan hasil belajar peserta didik.

Penggunaan strategi ini merupakan salah satu obat guna meminimalkan permasalahan yang muncul dalam pembelajaran. Dengan menayangkan suatu peta konsep dan meminta peserta didik untuk mengidentifikasi konsep-konsep yang ada dalam satu unit materi pelajaran kemudian menyusunnya ke dalam urutan berpikir sistematis, peserta didik diharapkan dapat memahami konsep IPS yang dipelajari.

Peta konsep merupakan salah satu strategi organisasi materi pelajaran yang bertujuan membantu pebelajar meningkatkan aktivitas peserta didik menemukan kebermaknaan konsep-konsep baru terutama dilakukan dengan mengenakan struktur organisasi materi pembelajaran sehingga hasil belajar juga meningkat. Strategi organisasi dapat terdiri atas pengelompokan ulang ide-ide atau istilah-istilah itu menjadi bagian yang lebih kecil. Strategi ini juga terdiri atas pengidentifikasian ide-ide atau fakta-fakta kunci dari sekumpulan informasi yang lebih besar. Pada proses ini ditekankan pada materi sejarah proses perkembangan kolonialisme dan imperialisme barat serta pengaruhnya di berbagai. Materi ini tergolong sulit dipahami secara langsung sehingga dengan dikelompokkan ke dalam peta konsep yang tersusun secara hirarkis memudahkan peserta didik dalam memahaminya dengan menarik dari sisi kekiniannya.

Salah satu pernyataan dalam teori Ausubel Ratna Wilis Dahar (2011, p.106) adalah 'bahwa faktor paling penting yang mempengaruhi pembelajaran adalah apa yang telah diketahui peserta didik (pengetahuan awal). Agar belajar jadi bermakna, maka konsep baru tentang peristiwa teraktual saat ini dikaitkan dengan konsep-konsep yang ada dalam struktur kognitif peserta didik. Ausubel belum menyediakan alat atau cara yang sesuai bagi guru untuk mengetahui apa yang telah diketahui oleh peserta didik Ratna Wilis Dahar, 
(2011, p.106). Berkenaan dengan itu Novak dan Gowin Ratna Wilis Dahar (2011, p.106) mengemukakan bahwa ada cara untuk mengetahui konsep-konsep yang telah dimiliki peserta didik, yaitu peta konsep.

Bermawy Munthe (2012,p.19) seorang guru dapat menggunakan peta konsep sebagai strategi dalam pembelajaran untuk beberapa kesempatan yaitu, peta konsep dapat digunakan untuk strategi mengajar, peta konsep dapat digunakan untuk strategi belajar bermakna.

Trianto (2011, p.160) memberikan langkahlangkah dalam membuat peta konsep yaitu sebagai berikut: 1) Mengidentifikasi ide pokok atau prinsip yang melingkupi sejumlah konsep, contohnya ekosistem, 2) Mengidentifikasi ide-ide atau konsep-konsep sekunder yang menunjang ide utama. Contoh, individu, populasi, dan komunitas, 3) Tempatkan ide-ide utama di tengah atau dipuncak peta tersebut, 4) Kelompokkan ide-ide sekunder di sekeliling ide utama yang secara visual menunjukkan hubungan ide-ide tersebut dengan ide utama.

Langkah-langkahpembelajaran dengan peta konsep menurut Hisyam Zaini.dkk (2008, p. 168) adalah sebagai berikut. a). pilihlah satu masalah atau topik atau teks maupun wacana bab sebagai bahan evaluasi, b). mintalah peserta didik melakukan brain storming (curah gagasan), c). mintalah peserta didik memilih 10-12 konsep-konsep utama, d). peserta didik menuliskan konsep-konsep utama diatas kartu-kartu secara terpisah, e). peserta didik untuk mencoba beberapa kali membuat satu gambar yang saling berhubungan antar konsep-konsep, f). peserta didik menulis satu kata atau level diatas setiap garis penghubung, g). Tampilkan satu peta konsep yang anda buat sendiri sebagai bahan perbandingan dengan apa yang dikerjakan peserta didik, h). Setelah peserta didik mengerjakan tugas, anda mengumpulkannya dan siap untuk melakukan koreksi atau bahan evaluasinya dengan kriteria yang sudah dibuat, i). Setelah dikoreksi, anda mengembalikannya kepada peserta didik.

Kemudian dari segi aktivitas kita ketahui bahwa pembelajaran merupakan suatu proses interaksi peserta didik dengan guru dan sumber belajar pada suatu lingkungan belajar. Dalam proses pembelajaran, aktivitas ini merupakan bagian penting untuk mencapai tujuan pembelajaran. Menurut Arief Sardiman (2006, p.100) aktivitas belajar adalah aktivitas yang bersifat fisik maupun mental. Jadi aktivitas yang diberikan kepada peserta didik harus mencakup hal yang berhubungan dengan kegiatan fisik yang membutuhkan gerak raga dan olah rasa atau mental.

Karena aktivitas belajar itu banyak sekali macamnya maka para ahli mengadakan klasifikasi atas macam-macam aktivitas belajar, diantaranya menurut Paul D. Dierich membagi aktivitas belajar menjadi 8 kelompok Sardiman (2006, p.101) yaitu a). visual activities(kegiatankegiatan), b). oral activities (kegiatan-kegiatan lisan), c). listening activities (kegiatan-kegiatan mendengarkan), d). writing activities (kegiatankegiatan menulis, e). drawing activities (kegiatan-kegiatan menggambar, f). motor activities (kegiatan-kegiatan pengukuran, g). mental activities (kegiatan-kegiatan mental, h). emotional aktivities (kegiatan-kegiatan emosional).

Meningkatnya aktivitas diharapkan hasil belajar peserta didik juga meningkat. Hasil belajar menurut Slameto $(2003$, p.3) yaitu perubahan yang terjadi dalam diri seseorang, berkesinambungan, dan tidak statis. Gagne (1975, p.63) menyatakan bahwa hasil belajar (output)nya adalah perubahan tingkah laku yang tampak dalam penampilan seseorang.

Nana Sudjana (2006, p.56) bahwa hasil belajar menunjukkan ciri-ciri sebagai berikut, (1). Kepuasan dan kebanggaan yang akan menumbuhkan motivasi belajar dari peserta didik, (2) menambah keyakinan akan kemampuan dirinya, bahwa peserta didik mempunyai potensi, (3) hasil belajar yang dicapainya bermakna bagi dirinya, membentuk prilakunya, bermanfaat untuk mempelajari aspek lain, dan mengembangkan kreativitasnya, (4) Hasil belajar diperoleh peserta didik secara menyeluruh (komprehensif), yaitu mencakup ranah kognitif, psikomotorik, ranah afektif, (5) kemampuan peserta didik untuk mengontrol atau menilai dan mengendalikan dirinya terutama menilai hasil yang dicapainya.

Pada penelitian ini juga dimanfaatkan beberapa media yang dapat membantu proses pembelajaran. Mencapai hasil yang maksimal dalam pembelajaran kita membutuhkan bantuan 
media dalam memberikan materi kepada peserta didik agar pembelajaran bisa lebih menarik. Menurut Syaiful Bahri Djamarah \&Aswan Zain (2010, p.120) kata "media" berasal dari bahasa Latin dan merupakan bentuk jamak dari kata "medium", yang secara harfiah berarti "perantara atau pengantar". Menurut Arief Sadiman, dkk (2002, p.6) media adalah perantara atau pengantar pesan dari pengirim ke penerima pesan. Dengan demikian, media merupakan wahana penyalur informasi belajar atau penyalur pesan. Menggunakan media kita berharap setiap ketidakjelasan dalam penjabaran materi pelajaran bisa menjadi lebih mudah dipahami peserta didik. Kerumitan dalam menyampaikan bahan pelajaran bisa disederhanakan dengan bantuan media.

Bisa dikatakan juga bahwa media merupakan sumber belajar, maka secara umum media bisa manusia, benda, ataupun peristiwa yang memungkinkan anak didik memperoleh pengetahuan dan keterampilan. Menurut Wina Sanjaya (2012, p.57) media adalah perantara dari sumber informasi ke penerima informasi, contohnya video, televisi, komputer dan lain sebagainya.

Faktor-faktor yang perlu diperhatikan dalam memilih media pengajaran Syaiful Bahri Djamarah\&Aswan Zain (2010, p.128) adalah:a). Objektivitas, b) program pengajaran, c) sasaran program, d) situasi dan kondisi, e) kualitas teknik, f) keefektifan dan efisiensi penggunaan. Faktor objektivitas di sini ditujukan agar guru dalam memilih media pengajaran jangan subjektivitas dalam artian guru memilih media yang akan digunakan adalah mencari media yang paling mudah dan berdasarkan kesenangannya saja. Pada program pengajaran yang akan disampaikan kepada anak didik guru harus memperhatikan kurikulum yang berlaku saat itu agar tujuan dari pembelajaran dapat tercapai.

Sasaran program media pembelajaran ini adalah peserta didik sendiri dan perlu juga diperhatikan situasi dan kondisi dalam pemilihan media yang akan disajikan. Kualitas teknik penyajian media serta keefektifan dan keefisienan penggunaannya perlu juga diperhatikan agar penyajian baik itu gambar maupun alat-alat bantunya menjadi lebih jelas dan lengkap.

Pembelajaran dengan target penguasaan materi pelajaran saja berhasil membawa peserta didik untuk mampu "mengingat" dalam jangka pendek, tetapi kurang dapat membekali peserta didik dalam kemampuan memahami dan menghubungkan suatu konsep dengan kejadian sebenarnya di lapangan, dalam jangka panjang. Dengan menggunakan strategi peta konsep diharapkan peserta didik mendapat pengalaman belajar yang bermakna dalam pembelajaran sehingga aktivitas dan kemampuan memahami suatu konsep atau fakta mudah diperoleh.

Maka tujuan dari penelitian ini adalah untuk mengetahui implementasi strategi peta konsep dapat meningkatkan aktivitas dan hasil belajar peserta didik, mengetahui kendala-kendala dan bagaimana mengatasi kendala-kendala yang ditemukan dalam proses pembelajaran IPS.

\section{Metode Penelitian}

Jenis Penelitian

Jenis penelitian yang di lakukan adalah Penelitian Tindakan Kelas (Classroom Action Reseach). Penelitian tindakan kelas (PTK) merupakan penelitian yang dilakukan di kelas untuk memperbaiki proses belajar mengajar oleh guru sebagai peneliti yang dibantu oleh kolaborator.

Waktu dan tempat penelitian

Penelitian ini dilakukan di SMP Muhammadiyah 3 Depok Sleman Provinsi Yogyakarta. SMP Muhammdiyah 3 Depok Sleman beralamat di Jln. Gejayan, Depok, Sleman, Yogyakarta.

Penelitian ini mulai dilaksanakan pada bulan Agustus 2013 sampai dengan bulan September 2013. Pengambilan data penelitian dilakukan pada bulan Agustus-September 2013. Penelitian dilaksanakan sejalan dengan proses pembelajaran yang sedang berlangsung, yaitu 4 jam pelajaran seminggu dengan 2 kali pertemuan masingmasing 40 menit.

\section{Target/Subjek Penelitian}

Instrumen pengumpulan data yang digunakan pada penelitian ini disesuaikan dengan teknik pengumpulan data yang telah ditentukan, yaitu (1) pedoman observasi aktivitas dan hasil belajar peserta didik, ini digunakan sebagai alat pengumpulan data yang diperoleh dari observasi mengenai penerapan peta konsep yang dicatat dan dikumpulkan untuk kemudian dianalisis lebih lanjut, (2) pedoman wawancara bebas, ini 
khusus digunakan untuk mengumpulkan data yang diperoleh dari hasil wawancara kepada guru IPS dan peserta didik yang dilakukan peneliti saat melakukan pengumpulan data di lapangan, (3) pedoman analisis dokumen, ini khusus digunakan untuk menganalisis dokumen-dokumen dalam pembelajaran IPS yang diperoleh di lapangan.

Lembar observasi berisi indikator aktivitas peserta didik dalam belajar IPS Terpadu di kelas. Indikator yang diamati adalah a) Aktivitas dalam kelas selama proses pembelajaran yaitu aktivitas membaca materi pelajaran yang akan disusun ke dalam beberapa konsep-konsep materi pelajaran yang telah diringkas, b) Aktivitas memberikan jawaban dalam diskusi kelompok dan kelas artinya aktivitas yang dilakukan oleh peserta didik dalam menjawab pertanyaan yang diberikan oleh guru ataupun pertanyaan peserta didik dari kelompoknya dan kelompok lainnya, c) Aktivitas mendengarkan dan menyimak materi pelajaran yang disampaikan guru dalam proses pembelajaran, d) Aktivitas mencatat hasil diskusi artinya aktivitas yang dilakukan peserta didik dalam mencatat hasil diskusi, baik hasil diskusi kelompok maupun hasil diskusi kelas. e) Aktivitas bekerjasama dalam diskusi, yaitu peserta didik saling bekerjasama dalam menyelesaikan tugas yang ada pada bahan diskusi dalam diskusi kelompok, f) Aktivitas memberikan bantuan dalam diskusi kelas artinya apabila peserta didikmemiliki motivasi atau semangat memberikan informasi atau ungkapan kepada temannya yang berkaitan dengan materi pelajaran baik diminta maupun tidak diminta.

Tabel 1. Kisi-kisi Lembar Observasi Aktivitas Guru dan Peserta didik

\begin{tabular}{|c|c|c|c|c|c|c|}
\hline \multirow{2}{*}{ No } & \multirow{2}{*}{ Indikator } & \multicolumn{5}{|c|}{ Skor } \\
\hline & & 1 & 2 & 3 & 4 & 5 \\
\hline 1 & Membaca materi & & & & & \\
\hline 2 & Memberikan argumen & & & & & \\
\hline 3 & Menyimak & & & & & \\
\hline 4 & Mencatat & & & & & \\
\hline 5 & Kerjasama kelompok & & & & & \\
\hline 6 & Semangat beraktivitas & & & & & \\
\hline
\end{tabular}

Prosedur

Prosedur penelitian yang digunakan dalam penelitian ini adalah model siklus yang melalui empat tahap yaitu: perencanaan (planning), tindakan (action), observasi (observation) dan refleksi (reflection). Diagram alur desain penelitian ditunjukan pada gambar 1 berikut ini.

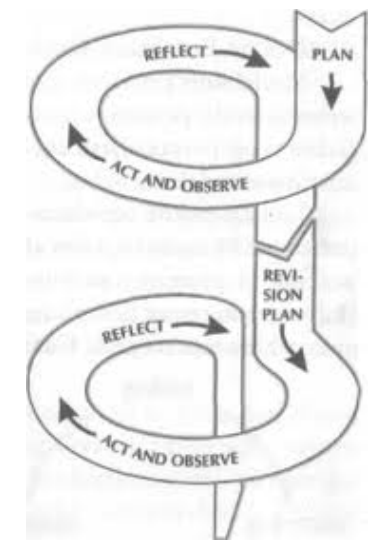

Teknik Analisis Data

Pada penelitian ini dilakukan analisis deskriptif kuantitaif terhadap aktivitas dan hasil belajar peserta didik. Berikut ini teknik analisis untuk aktivitas guru dan peserta didik. Data pengamatan aktivitas peserta didik baik individu dan dalam kerja kelompok dianalisis dengan menjumlahkan rata-rata skor peserta didik tiap indikator, kemudian skor tersebut diklasifikasikan menggunakan criteria berikut.

a. Aktivitas

Tabel 2. Klasifikasi Rerata Skor Aktifitas Guru dan Peserta Didik

\begin{tabular}{cccl}
\hline No & $\begin{array}{c}\text { Rerata } \\
\text { Skor }\end{array}$ & $\begin{array}{c}\text { Interval } \\
\text { Nilai }\end{array}$ & \multicolumn{1}{c}{ Klasifikasi } \\
\hline 1. & $>4,2$ & $81-100$ & Sangat baik \\
2. & $>3,4-4,2$ & $61-80$ & Baik \\
3. & $>2,6-3,4$ & $41-60$ & Cukup \\
4. & $>1,8-2,6$ & $21-40$ & Kurang \\
5. & $\leq 1,8$ & $0-20$ & Sangat Kurang \\
\hline
\end{tabular}

Sumber: Eko Putro Widoyoko 2013

b. Hasil Belajar

Penghitungan nilai hasil belajar

Nilai $=\frac{\text { Skor yang diperoleh peserta didik }}{\text { Skor Maksimum }} \times 100$

Ketuntasan belajar klasikal

Untuk mengukur ketuntasan belajar klasikal digunakan rumus: 
$\%$ Tuntas KKM $=\frac{\text { Jumlah peserta didik nilai } \geq 75}{\text { Jumlah Peserta didik keseluruhan }} \times 100 \%$

\section{Hasil Penelitian dan Pembahasan}

a. Aktivitas Peserta Didik

Tabel 3. Rekap Analisis Aktivitas Peserta Didik

\begin{tabular}{cccccc}
\hline \multirow{2}{*}{ No } & \multirow{2}{*}{ Aktivitas } & $\begin{array}{c}\text { Siklus } \\
\text { I }\end{array}$ & Nilai & $\begin{array}{c}\text { Siklus } \\
\text { II }\end{array}$ & Nilai \\
\hline 1 & $\begin{array}{l}\text { Membaca } \\
\text { materi }\end{array}$ & 3.50 & 70 & 3,58 & 71,6 \\
2 & $\begin{array}{l}\text { Memberikan } \\
\text { argument }\end{array}$ & 3,31 & 66,2 & 3,36 & 67,2 \\
3 & Menyimak & 3,53 & 70,6 & 3,64 & 72,8 \\
4 & Mencatat & 3,31 & 66,2 & 3,42 & 68,4 \\
5 & $\begin{array}{l}\text { Kerjasama } \\
\text { kelompok }\end{array}$ & 3,31 & 66,2 & 3,42 & 68,4 \\
6 & $\begin{array}{l}\text { Semangat } \\
\text { beraktivitas }\end{array}$ & 3.34 & 66,8 & 3,48 & 69,6 \\
\hline Total & rerata & $\mathbf{3 , 3 9}$ & $\mathbf{6 7 . 8}$ & $\mathbf{3 , 4 8}$ & $\mathbf{7 0}$ \\
\hline
\end{tabular}

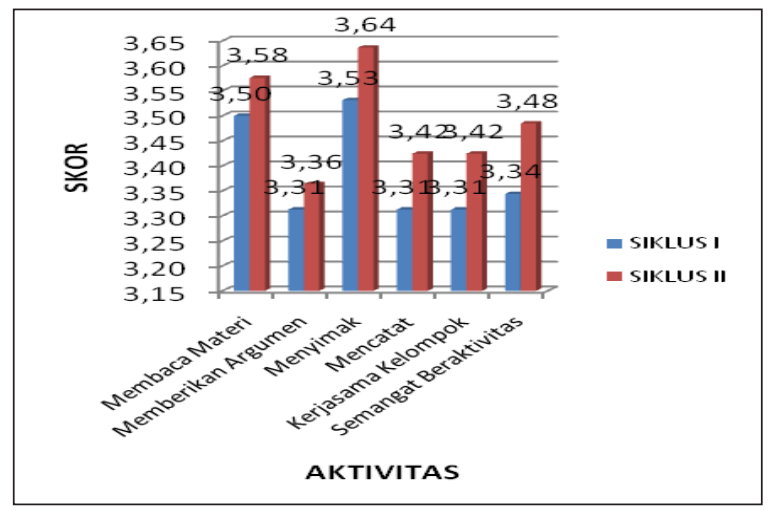

Gambar 1. Grafik Aktivitas Peserta Didik

Berdasarkan gambar di atas dapat kita simpulkan bahwa dari setiap tindakan di siklus yang dilakukan terdapat peningkatan aktivitas peserta didik. Peningkatan aktivitas peserta didik dari siklus I ke siklus II yaitu dari segi membaca materi pelajaran mengalami peningkatan senilai 0.08 , memberikan argumen senilai 0.05 , menyimak senilai 0.11 , mencatat senilai 0.11 , kerjasama kelompok senilai 0.11 , dan semangat peserta didik dalam beraktivitas dalam pembelajaran senilai 0.14 point. b. Aktivitas Guru

Tabel 4. Rekap Aktivitas Guru

\begin{tabular}{ccc}
\hline Tindakan & Total & Rerata \\
\hline SIKLUS I & 47 & 3.92 \\
SIKLUS II & 53 & 4.25 \\
\hline & \multicolumn{5}{c}{5} \\
\hline \\
\hline
\end{tabular}

Gambar 2. Aktivitas Guru

Aktivitas guru mengalami peningkatan dari siklus I 3, 92 atau senilai 78,4 menjadi 4, 25 atau 85 dari klasifikasi baik menjadi sangat baik. Peningkatan aktivitas guru ternyata juga memberikan pengaruh bagi aktivitas dan hasil belajar peserta didik. Penambahan kegiatan yang dilakukan guru dalam proses pembelajaran siklus I ke siklus II yaitu menambahkan permainan dan reward berhasil meningkatkan aktivitas dan hasil belajar peserta didik

c. Hasil Belajar

Tabel 5. Rekap Hasil Belajar

\begin{tabular}{llccc}
\hline No & Peserta & $\begin{array}{c}\text { Siklus } \\
\text { I }\end{array}$ & $\begin{array}{c}\text { Siklus } \\
\text { II }\end{array}$ & Peningkatan \\
\hline 1. & Pre Test & 56,0 & 62,4 & 6,4 \\
2. & Post Test & 70,6 & 86,4 & 15,8 \\
\hline & KKM & II & T & \\
\hline
\end{tabular}

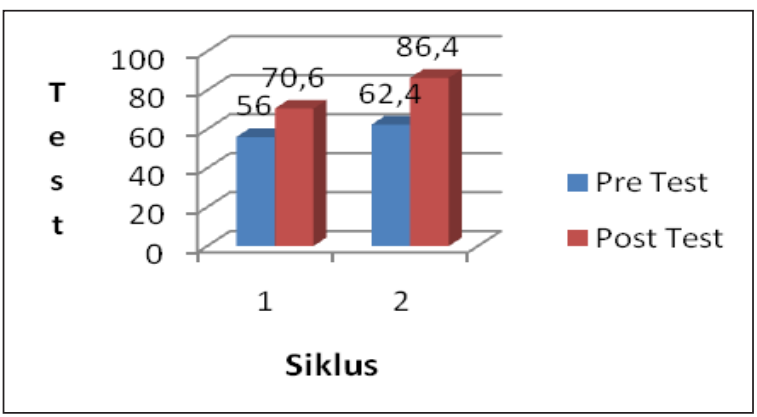

Gambar 3. Grafik Hasil Belajar 
Pelaksanaan Tindakan Siklus I

\section{Persiapan dan Perencanaan}

Hasil observasi pra-tindakan yang dilakukan oleh peneliti menunjukkan bahwa secara umum metode pembelajaran yang biasa di gunakan oleh guru adalah ceramah, guru lebih dominan menerangkan, siswa mengikuti dan mencatat. Pada tahap pertama ini, pembelajaran IPS Terpadu, dikembangkan dengan menggunakan metode kerja kelompok dan menggunakan media power point. Peserta didik akan di kondisikan untuk memilah konsep-konsep dari materi yang akan dipelajaridan guru membagi peserta didik ke dalam kelompok. Instrumen yang digunakan terdiri dari: (1) Perangkat pembelajaran, terdiri dari Silabus Pembelajaran (SP), Rencana Pelaksanaan Pembelajaran (RPP), Bahan ajar tentang kolonialisme dan imperialisme barat di nusantara, lembar soal pretest dan lembar soal post test, media pembelajaran peta konsep menggunakan media powerpoint, (2) lembar observasi aktivitas yang terjadi di kelas, baik aktivitas guru, siswa dalam proses pembelajaran.

\section{Implementasi Tindakan}

Pertemuan pertama pada siklus I dilaksanakan pada hari Rabu, 12 September 2013. Materi pokok pembelajaran pada pertemuan pertama adalah prosesperkembangan kolonialisme dan imperialisme barat, serta pengaruh yang ditimbulkannya diberbagai daerah dengan kompetensi peserta didik dapat memahami berbagai kebijakan pemerintah kolonial yang merugikan rakyat, peserta didik belajar bagaimana menghargai hak asasi manusia, mengembangkan sikap saling menghormati dan toleransi terhadap sesama.

Pada 5 menit pertama guru memberikan apersepsi dengan membaca salam, presensi kehadiran peserta didik. Selanjutnya guru memberikan pretes untuk mengetahui kemampuan awal yang dimiliki peserta didik selama 8 menit. Setelah peserta didik mengerjakan pretes guru memberikan penjelasan awal dalam pemahaman konsep proses imperialisme dan kolonialisme, dengan menyampaikan tujuan pembelajaran agar siswa tahu apa yang akan dicapai selama pembelajaran berlangsung. Kemudian guru menjelaskan materi awal dengan media powerpoint sekaligus menggali pengetahuan yang telah dimiliki peserta didik terhadap materi yang akan di pelajari.
Guru memberikan waktu 5 menit untuk mempelajari materi pelajaran yang telah dibagikan oleh guru, kemudian membagi kelompok yang terdiri dari 5-6 orang. Setiap kelompok mendapatkan tugas memilah konsep-konsep dari materi yang dipelajariyaitu kebijakan dan pengaruh kolonialisme. Masing-masing kelompok di minta mendiskusikan dan memilah konsep yang mereka temukan dalam materi itu, kemudian konsep yang telah di tulis dipilih atau diringkas menjadi lebih spesifik. Perwakilan masing-masing kelompok diminta membacakan konsep-konsep yang telah mereka temukan.

Proses memilah konsep yang dilakukan peserta didik mengajak mereka agar dapat berpikir secara sistematis. Kemudian guru membantu peserta didik menyusun secara hirarkis konsep yang telah mereka tulis menjadi suatu susunan yang sistematis dan mudah dipahami peserta didik. Penggunaan media powerpoint dalam menampilkan susunan peta konsep ini membantu peserta didik mendapatkan gambaran secara utuh materi pelajaran yang mereka pelajari pada pertemuan itu. Guru kemudian memberikan kesimpulan dari pembelajaran pada pertemuan tersebut. Setelah itu guru membagikan soal postes untuk mengetahui kemampuan peserta didik setelah mendapatkan tindakan pembelajaran dengan peta konsep.

\section{Observasi dan Analisis Tindakan I}

\section{1) Pengamatan terhadap Guru}

Penampilan guru pada pertemuan di siklus I ini guru telah mampu memberikan motivasi kepada peserta didik untuk berani bertanya dan mengajukan pendapat, walaupun pada kenyataannya belum semua peserta didik yang berani melakukan hal itu. Guru membimbing peserta didik untuk mengamati dan memilah konsepkonsep yang dipelajari. Aspek penilaianaktivitas telah dilaksanakan dengan cukup baik oleh guru yang mengampu pelajaran IPS di SMP Muhhamadiyah 3 Depok Sleman dan digunakan untuk mengumpulkan data perkembangan belajar peserta didik. Aktivitas guru dalam mempersiapkan proses pembelajaran telah baik, karena semua perangkat yang dibutuhkan selama pembelajaran telah disiapkan sebelum pembelajaran di mulai. 
Hasil pengamatan aktivitas guru dapat lihat pada tabel 4. Pada tabel di atas diperoleh data bahwa dalam pelaksanaan pembelajaran dengan strategi peta konsep diperoleh skor rerata skor 3,92. Jika didasarkan pada klasifikasi yang ditetapkan, maka skor rata-rata tersebut berada pada $>3,4-4,2$ dan berada pada klasifikasi baik. Rincian pengamatan aktivitas saat proses pembelajaran berlangsung yaitu 1)aktivitas mengembangkan dan mengorganisasikan materi, media (alat bantu pembelajaran)guru memperoleh rerata skor 4, 2) Merencanakan skenario kegiatan pembelajaran dengan rerata 4,4 point, 3 ) merancang pengelolaan kelasrerata 3, dan 4) merancang prosedur, jenis, dan menyiapkan alat penilaian 3,5 point sehingga diperoleh rerata keseluruhan 3,92 yaitu senilai 78,4 yang diklasifikasikan baik. Penilaian baik pada siklus I ini diperoleh guru denganmengadakan beberapa perbaikan utama yang dilakukan oleh guru dalam aktivitasnya dalam proses pembelajaran.

Guru pada siklus I ini masih terkendala dalam manajemen waktu dalam mengalokasikan waktu untuk eksplorasi, elaborasi dan konfirmasi kepada peserta didik dikarenakan jam masuk mata pelajaran IPS dilaksanakan sesudah istirahat sholat zuhur. Sehingga untuk menunggu peserta didik cukup berada dalam kelas sudah menghabiskan waktu lebih kurang 15 menit jam pelajaran. Perbaikan berikutnya yang harus diperhatikan guru yaitu pengelolaan kelas, peserta didik yang telah dibagi ke dalam beberapa kelompok. Beberapa diantara peserta didik mondar-mondir ke kelompok lain hanya sekedar melihat hasil kerja kelompok lain akibatnya kelas menjadi agak ribut dan kurang kondusif.

\section{2) Pengamatan terhadap Siswa}

Pengamatan terhadap aktivitas peserta didik pada siklus I dapat dilihat pada tabel 3 di atas. Pada siklus I ini, peserta didik telah cukup baik dalam memberikan perhatian terhadap pelajaran. Namun kerjasama peserta didik dalam kelompok masih ada yang berlangsung secara individual. Peserta didik sudah mampu berkomunikasi dalam menerima dan menyampaikan pendapat, baik sesama peserta didik, maupun dengan guru.

Peserta didik yang melakukan aktivitas yang baik di pembelajaran pada siklus I yaitu ada 18 orang, aktivitas cukup yaitu 12 orang dan kurang
2 orang. Pada penelitian ini peneliti menginginkan aktivitas peserta didik keseluruhan berada pada kategori baik yaitu $85 \%$, namun pada siklus I ini persentase pencapaian peserta didik baru mencapai $56 \%$ dari seluruh peserta didik yang ada dengan rerata keseluruhan 3,39 atau senilai 67,8 yaitu pada klasifikasi cukup. Rincian aktivitas yang diperoleh peserta didik yaitu membaca materi pelajaran dengan rerata 3,50 klasifikasi cukup, memberikan argumen 3,31 klasifikasi cukup, mendengar 3,53 klasifikasi baik, mengerjakan tugas tertulis 3,31 klasifikasi cukup, kerjasama kelompok 3,31dan semangat beraktivitas 3,34 dengan klasifikasi cukup.

Berdasarkan data dari analisis di tabel 5 di atas mengenai hasil belajar peserta didik dapat diambil kesimpulan peserta didik yang mencapai nilai Kriteria Ketuntasan Minimal sebanyak 14 orang yaitu sekitar 43, $75 \%$ dari total keseluruhan peserta didik. Berarti ada 19 orang peserta didik yang belum tuntas pada tindakan di siklus I ini. Pada penelitian ini diharapkan peserta didik mencapai KKM Klasikal 85\% dari total keseluruhan peserta didik. Jika dibandingkan antara perolehan nilai pretes peserta didik dengan hasil postes di siklus ini seperti dijelaskan pada hasil tes di atas terdapat hubungan yang signifikan antara hasil belajar peserta didik setelah tindakan dengan sebelum diberikan tindakan.

Refleksi

Ada beberapa permasalahan yang menghambat pelaksanaan proses pembelajaran dengan menggunakan strategi peta konsep, yaitu: 1) Guru belum mampu secara maksimal untuk mengatur waktu, 2) guru terlihat kurang tanggap dalam mengatasi kesulitan yang dialami peserta didik berkaitan dengan materi yang diberikan, 3) guru masih terkendala dalam melakukan penilaian aktivitas peserta didik, 4) guru terlihat belum mampu memberikan motivasi secara sempurna kepada peserta didik untuk aktif bertanya maupun mengeluarkan pendapat.

Hambatan yang dialami peserta didik, antara lain: 1) peserta didik belum terbiasa dengan penerapan strategi peta konsep dalam pembelajaran, 2) dalam melakukan kerja kelompok sebagian peserta didik masih bekerja secara individu 3) Belum semua peserta didik yang termotivasi mengemukakan pendapat atau argumennya, 
4) sebagian peserta didik masih terlihat kurang tekun dalam bekerja serta kurang efektif dalam memaksimalkan waktu.

Untuk mengatasi masalah ini, guru harus aktif dalam mendorong dan memotivasi peserta didik untuk aktif bertanya maupun mengeluarkan pendapat dengan cara memberikan reward berupa pemberian pena bagi setiap anggota kelompok yang berhasil menyelesaikan tugas kelompok terlebih dahulu dari kelompok yang lain dan cara ini akan diterapkan pada siklus II. Guru juga harus cepat tanggap terhadap permasalahan yang dialami peserta didik. Bila peserta didik mendapatkan masalah dalam pembelajaran, guru harus siap menerangkan secara mendalam sehingga peserta didik mengerti.

Pelaksanaan Tindakan Siklus II

\section{Persiapan dan Perencanaan}

Pada tahap kedua ini, pembelajaran IPS Terpadu, juga dikembangkan dengan menggunakan metode kerja kelompok dan di minta menyusun peta konsep pada kertas A3 yang telah disediakan guru untuk masing-masing kelompok. Pada tindakan kedua ini peneliti menambah kegiatan pembelajaran untuk memotivasi peserta didik dengan memberikan reward dan teknik tanya jawab dengan permainan snowball.

Instrumen yang digunakan terdiri dari: (1) Perangkat pembelajaran, terdiri dari Silabus Pembelajaran (SP), Rencana Pelaksanaan Pembelajaran (RPP), Bahan ajar tentang berbagai bentuk perlawanan daerah terhadap kolonialisme dan daerah persebaran agama Kristiani, lembar soal pretest dan lembar soal post test, media pembelajaran peta konsep (chart peta konsep beserta kartu-kartu konsep), (2) lembar observasi aktivitas yang terjadi di kelas, baik aktivitas guru, peserta didik dalam proses pembelajaran.

\section{Implikasi Tindakan}

Siklus II (18 September 2013), guru menyampaikan tujuan pembelajaran yang akan dicapai, guru menjelaskan nilai-nilai kehidupan yang akan dicapai setelah mempelajari materi "Perlawanan Berbagai Daerah terhadap Kolonialisme dan Imperialisme dan Penyebaran Agama Kristen di Tanah Air". Guru menampilkan tokoh-tokoh Nasional. Guru menjelaskan setiap perlawanan yang dilakukan oleh para pahlawan disetiap daerah sampai persebaran agama Kristen pada masa kolonialisme dengan media powerpoint. Selanjutnya siswa dibagi menjadi 6 kelompok yang terdiri dari 5-6 orang. Guru membagikan kertas kuarto A3 ke masing-masing kelompok untuk menyusun peta konsep perlawanan masing-masing daerah terhadap kolonialisme dalam waktu 15 menit.

Siswa berkompetisi dalam menyelesaikan tugas peta konsep. Kemudian masing-masing kelompok menempelkan hasil kerja mereka di papan tulis, 3 kelompok pertama yang selesai terlebih dahulu mendapatkan hadiah dari guru (reward). Setelah itu guru menampilkan peta konsep yang telah disediakan oleh guru untuk membandingkan dengan hasil kerja masingmasing kelompok, namun ada beberapa bagian yang dikosongkan untuk diisi oleh peserta didik dengan kartu konsep yang telah disediakan oleh guru. Menggunakan permainan snowball untuk menentukan siapa yang maju ke depan memasangkan kartu konsep yang ada ditangan guru. Guru kemudian memberikan kesimpulan dari proses pembelajaran pada tindakan di siklus II ini. Penilaian aktivitas peserta didik dilakukan saat pembelajaran berlangsung. Terakhir diadakan postes untuk mengetahui peningkatan hasil belajar pada siklus II.

\section{Observasi dan Analisis Tindakan II}

\section{1) Pengamatan terhadap Guru}

Penampilan guru pada pertemuan di siklus II telah terlihat peningkatan aspek quetioning dan motivating, di mana guru telah mampu memberikan motivasi kepada peserta didik untuk berani bertanya dan mengajukan pendapat, dan hampir sebagian besar peserta didik telah berani melakukan hal itu. Guru membimbing peserta didik untuk memahami dan memilah konsep-konsep yang dipelajari dan menulisnya dalam suatu bentuk peta konsep yang terstruktur.

Aspek penilaian telah dilaksanakan dengan sangat baik dan digunakan untuk mengumpulkan data perkembangan belajar peserta didik. Aktivitas guru dalam mempersiapkan proses pembelajaran telah sangat baik, karena semua perangkat yang dibutuhkan selama pembelajaran telah disiapkan sebelum pembelajaran di mulai. Rincian pengamatan aktivitas saat proses 
pembelajaran berlangsung yaitu 1)aktivitas mengembangkan dan mengorganisasikan materi, media (alat bantu pembelajaran) guru memperoleh rerata skor 4,67, 2) Merencanakan skenario kegiatan pembelajaran dengan rerata 4,4point, 3 ) merancang pengelolaan kelas rerata 3,5, dan 4) merancang prosedur, jenis, dan menyiapkan alat penilaian 4 point. sehingga diperoleh rerata keseluruhan 4,25 atau senilai 85 yang diklasifikasikan sangat baik.

\section{2) Pengamatan terhadap peserta didik}

Pada siklus II ini aktivitas peserta didik dalam proses pembelajaran. Kerjasama peserta didik dalam kelompok berlangsung secara tim telah menunjukkan kekompakan dalam menyusun peta konsep dan tidak lagi secara individual. Peserta didik mampu berkomunikasi dalam menerima dan menyampaikan pendapat, baik sesama peserta didik, maupun dengan guru. Peserta didik yang melakukan aktivitas yang baik di pembelajaran pada siklus II yaitu ada 29 orang, aktivitas cukup sebanyak 4 orang. Pada siklus II ini telah tercapai tingkat persentase aktivitas peserta didik berada pada kategori baik yaitu $88 \%$, dan cukup $12 \%$ dengan rerata keseluruhan 3,48 , yaitu pada klasifikasi baik. Rincian aktivitas yang diperoleh peserta didik yaitu membaca materi pelajaran dengan rerata 3,58 klasifikasi baik, memberikan argumen 3.36 klasifikasi cukup, mendengar 3,64 klasifikasi baik, mengerjakan tugas tertulis 3,42 klasifikasi baik, kerjasama kelompok 3,42 dan semangat beraktivitas 3,48 dengan klasifikasi sangat baik. Analisis aktivitas peserta didik dapat kita lihat pada tabel 3 di atas.

Berdasarkan data dari analisis hasil belajar peserta didik di tabel 5 dapat diambil kesimpulan peserta didik yang mencapai nilai Kriteria Ketuntasan Minimal sebanyak 28 orang yaitu sekitar $85 \%$ dari total keseluruhan peserta didik. Berarti ada 5 orang peserta didik yang belum tuntas pada tindakan di siklus II ini. Pada tindakan ini telah tercapai KKM Klasikal yang diharapkan peneliti yaitu $85 \%$ dari total keseluruhan peserta didik. Rerata pos test yang diperoleh peserta didik pada siklus II ini senilai 86,4 . Peningkatan hasil belajar peserta didik dapat di lihat pada tabel 17 yaitu peningkatan nilai pretest di siklus I ke siklus II senilai 6,4 point dan nilai postest 15.8 point. Peningkatan ini terjadi disebabkan oleh semakin meningkatnya aktivitas belajar peserta didik dan meningkatnya aktivitas guru serta penambahan pengunaan media dalam proses pembelajaran. Sehingga dapat diperoleh kesimpulan adanya hubungan antara peningkatan aktivitas dan penggunaan media dengan hasil belajar yang diperoleh oleh peserta didik. Tercapainya KKM klasikal pada tindakan kedua ini maka peneliti menghentikan penelitian pada siklus II ini.

\section{Refleksi}

Pada siklus II permasalahan yang masih menghambat pelaksanaan proses pembelajaran dengan menggunakan strategi peta konsep, yaitu: 1) Guru belum mampu secara maksimal untuk mengatur waktu, 2) guru masih terkendala dalam melakukan penilaian aktivitas peserta didik karena pengamatan terhadap aktivitas peserta didik dapat saja menjadi sangat subjektif. Namun pada dasarnya permasalahan yang muncul dapat diminimalisir dibandingkan pada siklus I.

Hambatan yang dialami peserta didik, antara lain: 1) peserta didik belum terbiasa dengan penerapan strategi peta konsep dalam pembelajaran, 2) sebagian peserta didik masih terlihat kurang tekun dalam bekerja serta kurang efektif dalam memaksimalkan waktu.

Untuk mengatasi masalah ini, guru harus memberikan batas waktu yang lebih ketat kepada peserta didik sehingga mereka dapat memaksimalkan waktu yang tersedia. Menelaah dari hasil penelitian yang dilakukan di atas dapat disimpulkan strategi peta konsep perlu dibiasakan dalam penyampaian materi pelajaran karena memberikan pengaruh yang signifikan dalam meningkatkan aktivitas dan hasil belajar peserta didik .

\section{Simpulan dan Saran}

Simpulan

1. Implementasi strategi peta konsep di SMP Muhammadiyah 3 Depok Sleman.

a. Meningkatkan aktivitas peserta didik kelas VIII D dalam proses pembelajaran .

Peningkatan aktivitas peserta didik dalam pembelajaran dari siklus I ke siklus II yaitu 0.09 dengan rerata keseluruhan 3,39 atau senilai 67,8 pada siklus I dengan klasifikasi cukup 
menjadi 3.48 yaitu 70 senilai pada siklus II dengan klasifikasi baik. Aktivitas guru dalam pelaksanaan pembelajaran dengan strategi peta konsep diperoleh skor rerata skor 3,92 atau senilai 78,4 pada siklus I menjadi 4,25 yaitu senilai 85 pada siklus II, maka telah terjadi peningkatan senilai 0,33 point. Peningkatan aktivitas peserta didik ini terjadi karena peneliti menambah permainan snowball dan pemberian reward dalam memotivasi semangat peserta didik dalam proses pembelajaran di siklus II.

b. Meningkatkan hasil belajar peserta didik kelas VIII D

Berdasarkan hasil tes peserta didik pada siklus I yang mencapai nilai Kriteria Ketuntasan Minimal sebanyak 14 orang yaitu sekitar 43, $75 \%$ dari total keseluruhan peserta didik. Setelah diadakan perbaikan dalam proses pembelajaran maka pada siklus II hasil belajar peserta didik mengalami peningkatan menjadi 28 orang yaitu seki$\operatorname{tar} 85 \%$ dari total keseluruhan peserta didik. Berarti ada 5 orang peserta didik yang belum tuntas pada tindakan di siklus II ini. Pada tindakan ini telah tercapai KKM Klasikal yang diharapkan peneliti yaitu $85 \%$ dari total keseluruhan peserta didik. Tercapai KKM klasikal pada tindakan kedua ini maka peneliti menghentikan penelitian pada siklus II ini. Meningkatnya aktivitas peserta didik dalam pembelajaran memberi pengaruh pada hasil belajar yang diperoleh peserta didik di siklus II.

2. Implementasi strategi peta konsep dapat membantu peserta didik berpikir secara sistematis terhadap konsep yang dipelajari sehingga pembelajaran menjadi bermakna. Berdasarkan penelitian ini dapat diketahui bahwa dengan strategi peta konsep dapat meningkatkan keaktifan peserta didik dalam aktivitas pembelajaran dan hasil belajar IPS pada materi proses perkembangan kolonialisme dan imperialisme barat serta pengaruhnya di berbagai daerah. Peningkatan ini dapat dicapai pada siklus II dengan penambahan aktivitas pembelajaran dengan permainan snowball dan pemberian reward kepada peserta didik.

3. Kendala-kendala dan bagaimana cara mengatasi kendala yang dihadapi dalam penerapan strategi peta konsep berbantuan media

a. Kendala-kendala yang dihadapi ini adalah masih lemahnya manajemen waktu dari peneliti dalam proses pembelajaran. Hal ini terjadi karena jam pelajaran IPS dimulai setelah istirahat sholat Zuhur, sehingga banyak dari peserta didik yang lalai masuk kembali ke kelas untuk memulai pelajaran berikutnya. Penilaian terhadap aktivitas peserta didik masih terkendala karena terbatasnya pengamatan terhadap setiap peserta didik dan kadang bersifat subjekif.

b. Upaya mengatasi kendala yang dihadapi dalam penerapan strategi peta konsep berbantuan media dapat dilakukan dengan pengalokasian waktu yang ketat dalam proses pembelajaran, dan memberikan batas waktu maksimal bagi peserta didik untuk diperbolehkan masuk kelas untuk pembelajaran berikutnya. Penilaian aktivitas peserta didik dapat dilakukan dengan penilaian antar mereka dalam melakukan aktivitas dalam proses pembelajaran.

Saran

1. Kepada guru, khususnya guru IPS Terpadu SMP Muhammadiyah 3 Depok Sleman, agar mendisain pembelajaran IPS Terpadu menggunakan strategi peta konsep agar lebih inovatif, dan berusaha mengimplementasikannya dalam pembelajaran IPS Terpadu di kelas dengan baik agar tujuan pembelajaran dapat tercapai dan dapat meningkatkan aktivitas dan hasil belajar peserta didik. Oleh karena itu perlu terus dikembangkan inovasi belajar IPS terpadu dan mata pelajaran lainnya di dalam kelas dengan menerapkan strategi peta konsep

2. Kepada peneliti selanjutnya

a. Dalam penelitian ini hanya meneliti pada aspek aktivitas dan hasil belajar peserta didik dengan menggunakan 
strategi peta konsep. Bagi para calon peneliti lainnya mungkin dapat melakukan tinjauan yang lain, seperti motivasi, karakteristik cara berpikir, kreativitas, minat peserta didik, dan lain-lain.

b. Hasil penelitian ini hanya terbatas pada standar kompetensi memahami proses kebangkitan nasional pada kompetensi dasar proses perkembangan kolonialisme dan imperialisme barat serta pengaruh yang ditimbulkannya diberbagai daerah sehingga masih memungkinkan untuk di ujicobakan pada standar kompetensi lainnya dengan mempertimbangkan kesesuaiannya.

\section{Daftar Pustaka}

Canas, A.J., Novak, J.D., Jhon. W., et al. (2003). A Summary of literature pertaining to the use of concept mapping techniques and technologies for education and performance support. Pensacola. The Institute for Human and Machine Cognition, di ambil pada tanggal 7 Oktober 2013. Http: / / cmapskm.ihmc.us/servlet/ SBReadResourceServlet?rid

Djamarah, S. B. \& Aswan. Z. (2010). Strategi belajar mengajar. Jakarta: Rineka Cipta.

Gagne, R. M. (1988). Prinsip-prinsip belajar untuk pengajaran. (Terjemahan Abdillah Hanafi \& Abdul Manan). New York: Holf, Rinehart and Winston. Buku asli diterbitkan tahun 1975).

Hamid, H. (1996). Pendidikan ilmu sosial. Jakarta: Dirjen Pendidikan Tinggi Proyek Pendidikan Tenaga Akademik.

Kemmis S \& Taggart R. (1990). The action research planner. Burwood: Deakin University Press.
Munthe, B. (2012). Desain pembelajaran. Yogyakarta: Pustaka Insan Madani.

Novak, J.D (2003). Learning, creating, and using knowledge: concept maps as facilitative tools in schools and corporations. Journal of e-Learning and knowledge Society vol. 6, n. 3, September 2010

(2000). The underlying consept maps and how to construct them. Diambil pada tanggal 24 Mei 2013, dari http: //cmap. coginst,uwf.edu/info/printer.html.

Putro Widoyoko, E. (2013). Evaluasi program pembelajaran. Yogyakarta: Pustaka Pelajar.

Sandjaya, W,.(2006). Pembelajaran dalam implementasi kurikulum berbasis kompetensi. Jakarta: Kencana Pranada Media Group.

Sardiman. (2006). Interaksi dan motivasi belajar mengajar. Jakarta: Raja Grafindo

Sadiman. et al.(2002). Media pendidikan (pengertian, pengembangan, dan pemanfaatannya). Jakarta: Raja Grafindo Persada.

Smaldino, S. E, et al. (2011).Instructional technology \& media for learning (Terjemahan Arif Rahman). Jakarta: Kencana Pranada Media Group.

Trianto. (2009). Mendesain model pembelajaran inovatif-progresif. Jakarta: Kencana Prenada Media Group.

Willis Dahar, R. (1989). Teori-teori belajar. Yogyakarta: Erlangga

(2011). Teori-teori Belajar \& pembelajaran. Jakarta: Erlangga 